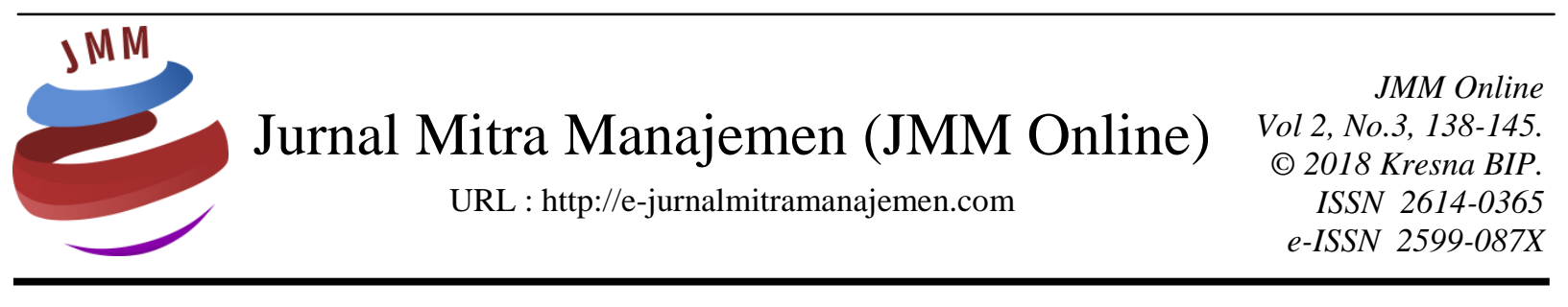

\title{
EFEKTIFITAS PENGELOLAAN KEWIRAUSAHAAN BERBASIS KOGNITIF PERSONAL MELALUI PENGGUNAAN INFRASTRUKTUR DIGITAL (MEDIA SOSIAL)
}

\author{
Misnawati $^{1)}$, Yusriadi ${ }^{2)}$ \\ Pendamping Program Keluarga Harapan (PKH) ${ }^{1)}$, \\ Sekolah Tinggi Ilmu Hukum Pengayoman ${ }^{2)}$
}

INFORMASI ARTIKEL

Dikirim : 06 Mei 2018

Revisi pertama : 21 Mei 2018

Diterima : 22 Mei 2018

Tersedia online : 30 Mei 2018

Kata Kunci : Manajemen,

Kewirausahaan, Kognitif, Infrastruktur Digital

Email : misnawati_amir@yahoo.com ${ }^{\text {l) }}$, yusriadi.yusriadi@uqconnect.edu.au ${ }^{2)}$

\section{ABSTRAK}

Efektifitas pengelolaan kewirausahaan ditentukan oleh beberapa aspek berhasil atau tidaknya suatu usaha yang dijalankan, yaitu aspek modal, pengelolaan, dan pemasaran. Profit suatu usaha bergantung pada strategi pemasaran yang dilakukan oleh wirausahawan.

Di era globalisasi ini, salah satu strategi pemasaran yang sangat efektif dilakukan adalah penggunaan infrastruktur digital dalam hal ini digital marketing melalui jejaring sosial. Namun penggunaan jejaring sosial seyogyanya didukung dengan kemampuan yang dimiliki oleh wirausahawan yang disebut dengan kognitif personal. Sinergitas antara kognitif personal wirausahawan dan pemanfaatan digital marketing berimplikasi terhadap kinerja suatu bisnis.

Tulisan ini mendeskripsikan efektifitas pengelolaan usaha melalui penggunaan infrastruktur digital berbasis kognitif personal seorang wirausahawan. Tulisan ini mengkaji tentang kewirausahaan melalui : (1) Efektifitas usaha yang didukung oleh kognitif personal; (2) Peran strategis media sosial dalam pengembangan kewirausahaan: dan (3) Implikasi kognitif personal terhadap efektifitas penggunaan infrastruktur digital. 


\section{PENDAHULUAN \\ Latar Belakang}

Dalam konteks persaingan global yang semakin terbuka seperti sekarang ini, banyak tantangan yang harus dihadapi. Setiap negara harus bersaing dengan menonjolkan keunggulan sumber daya masing-masing. Sumber-sumber ekonomi dapat diberdayakan apabila Sumber Daya Manusia (SDM) memiliki keterampilan dan pengetahuan yang cukup. Ada beberapa hal yang melatarbelakangi hal tersebut, diantaranya minimnya pengetahuan, minimnya keterampilan, sempitnya lapangan pekerjaan serta kurangnya perhatian dari pemerintah untuk menciptakan lapangan pekerjaan.

Kondisi lain menunjukkan bahwa menurut data BPS sampai bulan Agustus 2012 tingkat pengangguran justru lebih banyak diduduki oleh pengangguran terdidik (penganggur dengan latar belakang pendidikan D3 dan S1). Kondisi ini semakin meningkat dimana lulusan perguruan tinggi terus bertambah dan tidak diikuti dengan kemampuan pasar tenaga kerja untuk menyerap lulusan, menjadi faktor utama tingginya angka pengangguran tersebut. Padahal jika mereka memiliki kemampuan dalam mengelola sumber daya yang ada, seharusnya ada banyak kesempatan dan peluang dalam memanfaatkan sumber daya tersebut, misalnya dengan berwirausaha.

Kewirausahaan diyakini dapat menjadi faktor pendorong kemajuan suatu negara. Hal tersebut dapat dipahami karena sejumlah kecil wirausahawan tersebut dapat menciptakan lapangan pekerjaan kepada yang lainnya sehingga memberikan efek positif bagi perekonomian. Namun, sebelum seseorang memulai atau menciptakan suatu usaha, harus dan wajib baginya dalam meningkatkan pemahaman kewirausahaannya terkait usaha apa yang akan dirintis, bagaimana cara mengelola, strategi apa yang dibutuhkan dalam menunjang keberhasilan, bagaimana mengantisipasi dan mengatasi problematika yang muncul, dan lainnya. Disinilah pentingnya pengetahuan kewirausahaan yang dapat menjadi bekal sebelum memulai usaha. Pengetahuan itu dapat berupa konsep kewirausahaan, pola pikir, sikap, dan perilaku seorang dalam berwirausaha.

Walaupun demikian, apakah pengetahuan kewirausahaan menjadi satu-satunya faktor penentu efektifnya pengelolaan kewirausahaan?. Menurut Kalla (2011), pengetahuan penting untuk mempersiapkan calon wirausahawan, namun demikian pengetahuan tidak serta merta akan melahirkan seorang wirausahawan (Nursito \& Nugroho, 2013). Hal ini menunjukkan bahwa terdapat faktor lain yang dapat menunjang efektifitas pengelolaan kewirarausahaan, yaitu penggunaan infrastruktur digital dalam kewirausahaan. Infrastruktur yang dimaksud adalah infrastruktur telekomunikasi.

Menurut Zimmerer (2008), ada 8 faktor pendorong pertumbuhan kewirausahaan, salah satu diantaranya adalah kemajuan teknologi (Nordiana, 2014). Penggunaan teknologi dalam kewirausahaan akan memberikan banyak manfaat positif bagi keberhasilan usaha serta dapat memberikan banyak kemudahan dalam melakukan aktivitas berwirausaha, seperti kemudahan dalam mengakses informasi, perluasan jaringan dan juga untuk berkomunikasi. Maka itulah kemunculan media sosial dapat menjadi solusi yang efektif dalam menjalankan usaha berbasis teknnologi, seperti Facebook, Instagram, Shopee, Lazada, OLX, Bukalapak, dll. 
Kecanggihan situs jejaring sosial tersebut berfungsi sebagai sarana dalam melakukan kegiatan promosi, sehingga dengan mudah untuk saling bertukar informasi kepada siapa saja melalui fasilitas yang sudah ada. Dengan rendahnya anggaran yang harus dikeluarkan untuk mempromosikan produk yang dijual tentu ini merupakan nilai plus sebagai sarana promosi produk yang efisien dan rendah biaya.

Bagi seorang yang memiliki fokus untuk pengembangan wirausaha, dari penelitian ini, penulis melihat bagaimana efektifitas pengelolaan usaha jika didukung oleh kognitif personal wirausahawan, bagiamana peran strategis media sosial dalam pengembangan kewirausahaan, dan bagaimana implikasi infrastruktur digital terhadap efektifitas kognitif personal wirausahawan.

\section{PEMBAHASAN}

\section{Efektifitas Usaha Didukung oleh Kognitif Personal}

Kognisi adalah keyakinan seseorang tentang sesuatu yang didapatkan dari proses berpikir tentang seseorang atau sesuatu. Proses yang dilakukan adalah memperoleh pengetahuan dan memanipulasi pengetahuan melalui aktivitas mengingat, menganalisis, memahami, menilai, menalar, membayangkan dan berbahasa. Kapasitas atau kemampuan kognisi biasa diartikan sebagai kecerdasan atau inteligensi. Kepercayaan/ pengetahuan seseorang tentang sesuatu yang dipercaya dapat memengaruhi sikap mereka dan pada akhirnya memengaruhi perilaku/ tindakan mereka terhadap sesuatu (https://id.wikipedia.org, diakses tanggal 21/11/2017).

Untuk memulai sebuah usaha yang beriorientasi pada bisnis, seorang pemula harus ditopang dengan pengetahuan yang mumpuni terkait apa itu kewirausahaan dan bagaimana menjalankannya karena tanpa pengetahuan dasar terkait kewirausahaan tersebut maka pelaku wirausaha tidak akan tahu mau memulai dari mana untuk menjalankan bisnis mereka. Tidak hanya untuk pelaku bisnis pemula, kognitif personal pun sangat dibutuhkan pada mereka yang tengah menjalankan bisnisnya sebagai dasar bagi mereka untuk menjadi cekatan dan tanggap memikirkan dan menemukan solusi permasalahan dan bagaimana mempertahankan bisnis mereka ditengah kendala-kendala yang dihadapi.

Kemampuan atau keyakinan yang dimiliki seseorang dapat berefek kepada besar atau kecilnya minat dalam memulai atau menjalankan bisnis. Intensitas minat ini kemudian dipercaya dapat menunjang efektifitas dan keberhasilan suatu wirausaha/bisnis. Ini dapat dilihat dari penelitian yang dilakukan oleh Cham dan Purnama dan Suyanto pada industri kecil sepatu di Jawa Timur judul "Motivasi dan Kemampuan Usaha dalam Meningkatkan Keberhasilan Usaha Industri Kecil" menyimpulkan bahwa kemampuan usaha lebih dominan pengaruhnya terhadap keberhasilan usaha dibandingkan dengan motivasi usaha. Untuk itu perlu meningkatkan kemampuan usaha dengan mendahulukan meningkatkan sikap, kecerdasan emosional, keterampilan dan pengetahuan pengusaha dalam melakukan usahanya (Farida \& Widayanti, 2015). Lebih lanjut Chamdan dan Suyanto mengemukakan bahwa berbagai faktor penentu keberhasilan usaha industri kecil hasil identifikasi penelitiannya tersebut pada dasarnya merupakan cerminan dari kemampuan usaha (pengetahuan, sikap dan keterampilan), pengalaman yang relevan, motivasi kerja dan tingkat pendidikan seseorang pengusaha (Purnama \& Suyanto, 2010). 
Penelitian lain yang dilakukan pada Usaha Mikro Pedagang Sate di Desa Candiwulan Kecamatan Adimulyo Kebumen menguatkan bahwa dengan memiliki kemampuan usaha yang memadai pada diri pengusaha, pemahaman akan apa yang menjadi wewenang dan tanggungjawabnya, serta dibarengi adanya dorongan yang kuat untuk melakukan kegiatan usahanya, maka mereka akan tekun dalam bekerja, bekerja keras, penuh inisiatif dan kreativitas serta bertanggungjawab dalam melakukan tugas dan kewenangannya. Kondisi ini cenderung akan meningkatkan kepuasan para konsumen yang pada akhirnya akan membawa kearah keberhasilan suatu usaha (Azizah, 2013).

Dengan keadaan tersebut diatas dengan melihat beberapa hasil penelitian yang dilakukan oleh peneliti tersebut bahwa memang variabel kemampuan usaha memiliki peranan yang penting terhadap keberhasilan usaha kecil, namun didalam mempengaruhi keberhasilan usaha tersebut harus berjalan bersama-sama dengan indikator lainnya. Seorang pengusaha yang memiliki ketrampilan usaha memadai sulit untuk bisa meningkatkan keberhasilan usaha perusahaannya, tanpa memiliki kemauan kuat dari dalam untuk melakukan aktivitasnya di perusahaan (sikap). Begitu juga jika pengusaha kecil yang hanya memiliki kemauan tinggi, akan sulit untuk meningkatkan keberhasilan usahanya tanpa memiliki keterampilan dan pengetahuan untuk berkerja.

Meski diketahui bersama bahwa kemampuan usaha tidak dihasilkan dalam proses yang pendek, bahkan dalam perjalanannya memerlukan berbagai proses jatuh bangun sehingga ketahanan mental seorang pengusaha sangat diuji. Untuk itulah dengan kemampuan usaha yang dimiliki, sangat berperan penting dalam mempengaruhi keberhasilan usaha industri baik itu industri kecil, terlebih lagi industri besar.

\section{Peran Strategis Infrastruktur Digital dalam Pengembangan Kewirausahaan}

Perkembangan teknologi informasi sangat berkembang pesat. Berbagai kegiatan bisnis kecil sampai besar memanfaatkan perkembangan ini untuk menjalankan usahanya. Banyaknya competitor menjadi pertimbangan bagi para pengusaha untuk masuk dalam persaingan yang sangat ketat. Langkanya SDM yang handal dalam mengelola teknologi informasi merupakan sebuah bidang yang baru dimana Negara pada umumnya jarang memiliki SDM yang handal di bidang teknologi informasi (Yusriadi, 2018), sedangkan teknologi informasi ini sangat berpengaruh terhadap kepentingan strategi pemasaran suatu bisnis. Strategi pemasaran dapat dilakukan dengan media yang tepat untuk bisa meraih pasar yang dituju sehingga volume penjualan selalu meningkat dan profit. Strategi pemasaran yang tepat akan mendukung kesuksesan suatu bisnis, menjadikan lebih efektif dan efisien sesuai dengan STP (segmentasi, target pasar, positioning) yang dituju oleh suatu bisnis tersebut. Dimasa kini, salah satu strategi yang tepat untuk melakukan pemasaran produk melalui Infrastruktur Digital.

Infrastruktur Digital dalam hal ini tools marketing adalah salah satu media pemasaran yang saat ini sedang banyak diminati oleh masyarakat untuk mendukung berbagai kegiatan yang dilakukan. Mereka sedikit demi sedikit mulai meninggalkan model pemasaran konvensional/tradisional beralih ke pemasaran modern yaitu melalui digital marketing, seperti jejaring sosial. Dengan jejaring sosial komunikasi dan transaksi dapat dilakukan setiap waktu/real time dan bisa mengglobal atau mendunia. 
Dengan jumlah pengguna sosial media berbasis chat ini yang banyak dan semakin hari semakin bertambah membuka peluang bagi UKM untuk mengembangkan pasarnya dalam genggaman smartphone (Pradiani, 2017). Hingga tahun 2017, jumlah pengguna internet di Indonesia mencapai 143,26 juta jiwa. Angka tersebut meningkat dibandingkan pada tahun sebelumnya, yakni tahun 2016 yang tercatat mencapai 132,7 juta jiwa (https://ekonomi.kompas.com, diakses tanggal 19/02/2018).

Media sosial sebagai sebuah media online dengan berbagai fitur kemudahan yang bisa diperoleh penggunanya, bisa dengan mudah berpartisipasi, berbagi di dunia virtual lainnya. Media social yang menjadi minat pakai masyarakat saat ini adalah, Facebook, Instagram, WhatsApp, LINE, dan lain-lain. Disebut jejaring karena kemampuannya untuk saling terhubung dengan cepat antara satu domain komunitas dengan komunitas lainnya sehingga peluang dan kesempatan ini bisa dengan mudah dipergunakan untuk kepentingan bisnis atau usaha. Akan tetapi banyak dari kita yang belum dan tidak mengerti bagaimana cara mengfungsikan media sosial dalam dunia bisnis. Padahal kesempatan ini bisa digunakan dengan baik dalam mengorientasikan bisnis ke dalam jejaring sosial. Bahkan kini telah ada aplikasi digital yang penggunaannya khusus untuk penjualan dan marketing, seperti Lazada, Shopee, OLX, Bukalapak, dll. Aplikasi ini khusus diperuntukkan oleh pelaku bisnis dan konsumen bisnis sebagai strategi pemasaran produk yaitu promosi.

Promosi adalah kegiatan dalam pemasaran yang dilakukan dengan cara memperkenalkan barang kepada masyarakat dan bertujuan untuk meningkatkan penjualan. Promosi merupakan salah satu alat untuk mempengaruhi konsumen, baik langsung maupun tidak langsung. Sehubungan dengan teknologi, promosi disini dilakukan melalui online sehingga efektifitas kinerja bisnis tercapai, ditambah lagi dengan penggunaan tenaga dan modal yang lebih sedikit.

Susrini mengemukakan tentang beberapa keuntungan memiliki bisnis online, yaitu:

1. Modal yang dibutuhkan untuk membuat toko online sangat minim, kita hanya butuh aplikasi e-commerce (banyak yang tersedia gratis) dan biaya koneksi internet;

2. Untuk komponen tempat, toko online bisa memanfaatkan tempat (domain dan hosting) yang tersedia gratis di internet. Tapi kalau memilih tempat yang bayar, biayanya yang dibutuhkan kurang lebih Rp 600.000 pertahun. Jauh lebih, murah dari sewa toko fisik;

3. Toko online punya jangkauan yang lebih luas dibandingkan toko fisik;

4. Waktu operasional tidak terbatas (Susrini, 2017)

Salah satu strategi yang mendukung dalam pengembangan usaha, dapat dilakukan dengan membuat website, ada dua hal yang sangat penting yaitu "Domain" dan "Hosting". Domain yaitu identitas sebuah website di internet sebagai contoh https://bit.ly/Ninastore-website. Domain biasanya didapat dengan cara membeli dari lembaga pengelola domain atau para reseller domain. Hosting adalah tempat untuk menyimpan data dan file website di sebuah server yang terhubung dengan jaringan internet. Biasanya website mempunyai link ke Facebook dan Twitter. Strategi ini penting, karena perusahaan yang menggunakan media sosial sebagai tempat promosi jangkauannya lebih luas dibandingkan dengan perusahaan yang tidak menggunakannya. 
Seperti pada penelitian yang dilakukan pada Usaha Mikro Kecil dan Menengah (UMKM) menunjukkan bahwa mayoritas pelaku bisnis UMKM telah menggunakan dan memanfaatkan aplikasi media sosial untuk bisnis mereka. Manfaat yang dirasakan pelaku UMKM antara lain sebagai alat promosi produk atau jasa, memperluas akses terhadap pelanggan baru, memudahkan transaksi bisnis dengan pelanggan dan pemasok serta meningkatkan penjualan. Hasil dari penelitian ini menunjukkan bahwa aplikasi media sosial adalah alat yang paling efektif dalam pemberdayaan UMKM. Masukan bagi peningkatan kebijakan pemerintah untuk mendorong keterlibatan UMKM dalam ekonomi digital adalah peningkatan pembangunan infrastruktur dan kemudahan biaya dan akses internet yang murah, khususnya untuk wilayah terpencil (Srirejeki, 2016).

Begitupun pada penelitian yang dilakukan dengan judul "Literasi Digital Pada Perempuan Pelaku Usaha Produktif di Daerah Istimewa Yogyakarta" menunjukkan bahwa perempuan pelaku usaha produktif di DIY memamfaatkan literasi digital sebagai alat mengakses informasi guna mendukung kegiatan penjualan. Literasi digital dipandang memainkan peran penting dalam keberlanjutan kegiatan usaha produktif perempuan. Adopsi literasi digital inovatif terhadap bisnis usaha terbukti meningkatkan kemampuan perempuan dalam memajukan kegiatan UMKMnya (Widyastuti \& Nuswantoro, 2016).

Lebih lanjut penelitian yang dilakukan dengan judul "Pengaruh Sistem Pemasaran Digital Marketing Terhadap Peningkatan Volume Penjualan Hasil Industri Rumahan" menunjukkan bahwa digital marketing dipandang sebagai media yang paling baik sebagai sarana promosi yang paling efektif dan efisien serta mampu meningkatkan volume penjualan yang signifikan, dari pendapatan perbulan bersih Rp. 1.000.000,- s.d. Rp. 1.500.000,- sekarang bisa mencapai Rp. 2.000.000 s.d. 3.500.000,(100\%) (Pradiani, 2017).

Dengan data tersebut diatas dengan melihat beberapa hasil penelitian yang dilakukan oleh peneliti tersebut bahwa memang variabel infrastruktur digital dalam hal ini digital marketing memiliki peranan yang penting terhadap keberhasilan suatu usaha baik usaha kecil, menengah maupun usaha besar. Hal ini menguatkan bahwa melalui strategi pemasaran yang tepat akan mendukung kesuksesan suatu bisnis, serta menjadikannya lebih efektif dan efisien.

\section{Implikasi Kognitif Personal Terhadap Efektifitas Penggunaan Infrastruktur Digital}

Kognitif personal dalam hal kemampuan berwirausaha seseorang memiliki peranan yang sangat penting terhadap keberhasilan usaha pelaku wirausaha. Kognitif personal pelaku wirausaha mampu mempengaruhi minat kerja seseorang sehingga berimplikasi kepada profit perusahaan dan atau keberhasilan usaha tersebut. Namun hal ini harus berjalan bersama-sama dengan indikator lainnya seperti kemauan kuat dari pelaku usaha untuk melakukan aktivitasnya di perusahaan, indikator ini lebih kepada sikap pelaku wirausaha dalam menjalankan usahanya karena keterampilan usaha saja tidak cukup. Begitu juga sebaliknya jika hanya memiliki kemauan tanpa memiliki keterampilan dan pengetahuan kerja.

Sedangkan infrastruktur digital atau digital marketing menjadi salah satu strategi paling efektif dalam meraih keberhasilan suatu usaha jika melihat fenomena 
saat ini dimana sistem digital menjadi salah satu hal yang tidak bisa lagi dipisahkan dari kehidupan pribadi manusia. Mayoritas bisnis yang muncul di era modern saat ini cenderung dimanfaatkan melalui media online. Pateli dan Giaglis (2005) menyatakan bahwa percepatan pertumbuhan Teknologi Informasi dan Komunikasi (ICT) mampu meningkatkan tren yang mengubah model bisnis tradisional atau mendorong berdirinya bisnis baru (startup) yang cenderung memanfaatkan peluang teknologi (Nugraha \& Wahyuhastuti, 2017). Variabel ini menguatkan bahwa terdapat banyak peluang dan kesempatan keberhasilan kinerja bisnis melalui pemanfaatan dan penggunaan digital marketing.

Pengetahuan dan kemampuan seseorang dalam mengoperasikan segala bentuk infrastruktur digital sangat berimplikasi terhadap efektifitas suatu keberhasilan dan kinerja bisnis. Kognitif personal para pelaku wirausaha harus diasah terus menerus untuk selalu up to date terhadap perkembangan zaman yang cenderung menitikberatkan pada perkembangan digital yang semakin hari semakin canggih perkembangannya. Pelaku usaha harus pandai dalam memanfaatkan peluang digital untuk mengelola bisnis mereka karena bukan tak mungkin lagi sepuluh tahun kemudian profit penjualan produk dikuasai oleh aplikasi digital marketing.

\section{KESIMPULAN DAN SARAN Kesimpulan}

Dalam pengembangan kewirausahaan, baik untuk pelaku wirausaha pemula maupun yang sudah berpengalaman dalam mengelola usaha, kemampuan seorang pengusaha menjadi peranan yang sangat penting terhadap keberhasilan suatu usaha. Kemampuan tidak dihasilkan dalam proses yang pendek melainkan melalui proses jatuh bangun pelaku wirausaha. Sedangkan infrastruktur digital (digital marketing) menjadi salah satu strategi penting dalam melakukan pemasaran yang tepat untuk mendukung kesuksesan suatu bisnis. Hal ini tentunya didasari oleh pengetahuan dan kemampuan seseorang dalam mengoperasikan segala bentuk infrastruktur digital yang semakin hari semakin canggih perkembangannya yang berimplikasi terhadap pemanfaatan peluang digital dalam mengelola bisnis untuk mencapai profit penjualan produk melalui aplikasi digital marketing.

\section{Saran}

Dalam pengelolaan kewirausahaan, diperlukan sebuah kemampuan atau keterampilan (kognitif) sebagai suatu modal dalam memulai atau menjalankan sebuah usaha. Kemampuan pelaku usaha tidak hanya berupa kemampuan pengelolaan fisik melainkan juga kemampuan dalam melakukan pemasaran melalui pemanfaatan Infrastruktur Digital (Media Sosial). Oleh karena itu, sebagai pelaku usaha baik pemula maupun yang berpengalaman seharusnya jeli dalam melihat setiap kesempatan dan peluang yang ada dalam mendukung kinerja atau keberhasilan suatu usaha. Salah satu kesempatan dan peluang untuk pencapaian target kinerja usaha tersebut adalah melalui pemanfaatan Infrastruktur Digital dalam hal ini media sosial. 


\section{DAFTAR PUSTAKA}

Azizah, S. N. 2013. Pengaruh Motivasi Usaha dan Kemampuan Usaha dalam Meningkatkan Keberhasilan Usaha Pada Usaha Mikro Pedagang Sate di Desa Candiwulan Kecamatan Adimulyo Kebumen. Jurnal Fokus Bisnis, 12(01)

Farida, E., \& Widayanti, R. 2015. Analisis Pengaruh Motivasi, Kemampuan Kerja dan Jiwa Wirausaha terhadap Keberhasilan Usaha pada Sentra Kripik Tempe Sanan Malang. Jurnal Akuntansi, Bisnis, dan Manajemen, 22(01)

Nordiana, E. 2014. Peran Jejaring Sosial Sebagai Media Peningkat Minat Berwirausaha Mahasiswa Untuk Berbisnis Online (Studi Pada Mahasiswa Jurusan Ilmu Ekonomi Universitas Brawijaya)

Nugraha, A., \& Wahyuhastuti, N. 2017. Start Up Digital Business: Sebagai Solusi Penggerak Wirausaha Muda. Jurnal Nusamba, 2(01)

Nursito, S., \& Nugroho. 2013. Analisis Pengaruh Interaksi Pengetahuan Kewirausahaan dan Efikasi Diri Terhadap Intensi Kewirausahaan. Kiat BISNIS, 05(03)

Pradiani, T. 2017. Pengaruh Sistem Pemasaran Digital Marketing Terhadap Peningkatan Volume Penjualan Hasil Industri Rumahan. JIBEKA, 11(02)

Purnama, C., \& Suyanto. 2010. Motivasi dan Kemampuan Usaha dalam Meningkatkan Keberhasilan Usaha Industri Kecil (Studi Pada Industri Kecil Sepatu di Jawa Timur). Jurnal Manajemen dan Kewirausahaan, 12(02)

Srirejeki, K. 2016. Analysis Of The Use Of Social Media To Empower Small Micro Medium Enterprise (SMEs). Jurnal Masyarakat Telematika dan Informasi, 7(01)

Susrini. 2017. Peran Media Sosial di Era Modern. UI Press

Widyastuti, D. A., \& Nuswantoro, R. 2016. Literasi Digital Pada Perempuan Pelaku Usaha Produktif Di Daerah Istimewa Yogyakarta. Jurnal ASPIKOM, 3(01)

Yusriadi. 2018. Manajemen Perubahan dalam Reformasi Birokrasi menuju Information Technology (IT). Jurnal Mitra Manajemen, 2 